MARIA RUDNICKA

ORCID 0000-0002-1890-1320

Uniwersytet Wrocławski

\title{
GALERIA HANDLOWA JAKO PRZESTRZEŃ EDUKACJI NIEFORMALNEJ
}

\begin{abstract}
AвSTRACt. Rudnicka Maria, Galeria handlowa jako przestrzeń edukacji nieformalnej [The Shopping Mall as a Space of Informal Education]. Studia Edukacyjne nr 54, 2019, Poznań 2019, pp. 173-198. Adam Mickiewicz University Press. ISSN 1233-6688. DOI: 10.14746/se.2019.54.11

The goal of the study is to answer the question about the educational values of cultural promotional events held in shopping malls. To achieve this goal, an ethnographic research was performed during three events in two shopping malls in Wrocław. It consisted of participatory observation and interviews with 6 participants of the events.

The research is based on Knud Illeris's theory of learning through everyday life (non-formal learning). During the study, it was observed that the organizers of the events use the newest methods of learning (including new technologies). The information is transferred in various ways and the extra attractions that are part of the events engage participants in creative activities. The gained knowledge can be theoretical or practical and it can encourage participants to change their life habits or to undertake various activities in their lives. It also makes accessible the previously inaccessible areas of reality. New knowledge usually does not create new structures and basically reconstructs the existing ones (accommodation learning).

The learning process in shopping malls during the cultural events is a byproduct or a side effect of promotional activities, yet it takes place and it can improve the quality of life of the participants. Thus, a shopping mall, an institution of the consumer society, becomes an institution of the society of knowledge.
\end{abstract}

Key words: shopping mall, learning through everyday life, event

\section{Wprowadzenie}

W metropoliach istnieje wiele możliwości uczenia się w sposób nieintencjonalny. Może to dziać się w przestrzeni otwartej, gdzie na przykład idący starówką miejską obejrzy wystawę obrazującą historię jednej z dzielnic miasta, lub w przestrzeni zamkniętej. Pod tym pojęciem autorka artykułu rozumie galerie handlowe, które od niedawna przejęły rolę rynków wielkich miast. 
Oferują one nie tylko możliwość zrobienia zakupów, ale także spędzenia czasu zarówno w licznych kawiarniach oraz innych lokalach gastronomicznych lub w strefie relaksu, jak też podczas organizowanych przez zarządców galerii eventów, których główną intencją jest zachęcenie potencjalnych klientów do zrobienia zakupów. Wśród nich można wymienić: wystawy (np. prac dziecięcych, samochodów), bezpłatne lekcje tańca, czy spotkania z ekspertami (np. ze stylistką) lub ze znanymi postaciami (np. z Robertem Makłowiczem czy Ewą Wachowicz $\left.{ }^{1}\right)$, darmowe rozliczanie PIT-ów. Ich tematyka może być bardzo szeroka.

Zjawisko wiedzy zdobywanej mimowolnie pojawia się już w refleksji pedagogicznej - o możliwościach uczenia się w społeczeństwie konsumpcyjnym pisała Kamila Rudnicka²; świadomość taką mają także coraz częściej sami uczestnicy popkultury (np. osoby grające w gry komputerowe lub planszowe sami zauważają, jak wiele mogą dowiedzieć się w trakcie rozrywki). Nie opisano jednak dotąd edukacji zachodzącej podczas działań promocyjnych, dlatego w artykule tym autorka postara się pokazać potencjał edukacyjny eventów oraz to, w jaki sposób uczestnictwo w nich może podnieść jakość życia jednostek.

W części teoretycznej artykułu opisane zostaną problemy związane z edukacją: zależność między uczeniem się a kulturą oraz obszary edukacji dorosłych. Pokazane zostanie, jak ukształtowało się społeczeństwo konsumpcyjne oraz jak handel stopniowo stawał się coraz ważniejszym elementem kultury. Opisany będzie także fenomen galerii handlowych. Druga część artykułu to opis badania etnograficznego: wnioski z obserwacji eventów uzupełnione o wypowiedzi uczestników tych wydarzeń. Wszystko po to, aby odpowiedzieć na pytanie, w jaki sposób wydarzenia kulturalne (eventy) organizowane w galeriach handlowych mogą uczyć czegoś.

$\mathrm{W}$ odpowiedzi na to pytanie powinny pomóc poniższe problemy szczegółowe:

1. Jakiego rodzaju treść edukacyjną może nieść event: umiejętności praktyczne, wiedzę o świecie, wyzwalanie samoświadomości, wartości, postawy?

2. Jakie środki stosowane są do zachęcenia w udziale i przekazania treści edukacyjnej (strona wizualna, nagrody, wywołanie emocji)?

3. Jakie reakcje budzi event: czy wywołuje interakcje między uczestnikami, jeśli tak, jakiego typu?

${ }^{1}$ Niektóre z nich budzą kontrowersje. Dość wspomnieć o dwóch wydarzeniach: wystawie „Bodies - The Exhibiotion” (organizowano ją kilkakrotnie w różnych miejscach) oraz o ślubie w katowickiej galerii Silesia City Center.

${ }^{2}$ K. Rudnicka, Edukacja mimowolna. W poszukiwaniu nowych przestrzeni edukacyjnych w spoteczeństwie konsumpcyjnym, [w:] Kultura i edukacja (konteksty i kontrowersje), red. W. Jakubowski, Kraków 2008. 
4. Jak oceniana jest wartość eventów przez osoby biorące w nich udział?

Należy jeszcze uporządkować pojęcia i wyjaśnić terminologię. Zamiennie $\mathrm{z}$ pojęciami galeria handlowa i dom towarowy $\mathrm{w}$ artykule stosowane będą: mall i shopping mall ${ }^{3}$. W tym ostatnim sformułowaniu zawiera się pierwotna idea galerii jako miejsca pełniącego funkcje: komercyjną i publiczną (shopping - robienie zakupów, mall - deptak).

Słowo event, które pojawia się $\mathrm{w}$ tytule i jego treści, jest zapożyczeniem z języka angielskiego. Znaczy 'wydarzenie, przypadek, konkurencja'. W języku polskim istnieje słowo wydarzenie, jednak, choć jest ono najbliższe znaczeniowo wobec opisywanego zjawiska ('1) coś, co się stało, wydarzyło, miało miejsce, wypadek, przypadek; 2) ważne zdarzenie lub wybitne osiągnięcie w jakiejś dziedzinie'), jest zbyt ogólne, w związku z czym - niewystarczające. Natomiast pod hasłem wydarzenia kulturalnego rozumie się „zaplanowane spotkanie, którego celem jest pokazywanie, propagowanie kultury samej w sobie". Żadna z powyższych definicji nie oddaje specyfiki opisywanego zjawiska, dlatego wzorując się na terminologii public relations, przyjęto termin event, znaczące tyle, co „wydarzenie (może być wydarzenie kulturalne), którego podstawowym celem jest zachęcenie klientów do odwiedzenia centrum handlowego, spędzenia tam czasu i konsumpcja szeroko rozumianych dóbr i usług".

\section{Kultura jako przestrzeń uczenia się}

Kulturę tworzą rzeczy, myśli, idee oraz reguły operowania nimi. Jest ona narzędziem komunikacji oraz nośnikiem systemu wartości i celów powszechnie uznawanych za ważne, dyktuje to, co jest doniosłe, istotne; zespala i integruje ludzi, którzy ją tworzą i jej podlegają, a także stymuluje i warunkuje rozwój jednostki, pozwalając korzystać ze swojego dorobku4. To zbiór tekstów zawierających opis naszego świata. To właśnie w kontakcie z nią uczymy się wzorów zachowań, ról społecznych oraz możliwych scenariuszy własnych biografii ${ }^{5}$. Tak więc kultura jest przestrzenią edukacyjną.

Człowiek mógł stać się współtwórcą kultury i przystosować się do warunków życia w niej ze względu na zdolności uczenia się wykraczające poza osobiste doświadczenie. Jednostka, aby stać się normalnym uczestnikiem grupy, musi być wprowadzona w kulturę swego społeczeństwa - dzieje się

${ }^{3}$ Por.: mall [hasło w:] Słownik marketingu, red. J. Słupski, Seria: Biblioteka Profesjonalisty, Warszawa 2000, s. 131.

${ }^{4}$ A. Kłoskowska, Kultura masowa: krytyka i obrona, Warszawa 2005, s. 20.

${ }^{5}$ Zob. W. Jakubowski, Wstęp, [w:] Kultura jako przestrzeń edukacyjna - wspótczesne obszary uczenia się osób dorostych, red. W. Jakubowski, Kraków 2012, s. 7. 
to $\mathrm{w}$ procesie socjalizacji. Uczenie się jest podstawowym sposobem przekazywania kultury. Zatem, wiedza to podstawa istnienia i funkcjonowania społeczeństw, a uczestnictwo w nich to uczestnictwo w kulturze ${ }^{6}$.

\section{Obszary edukacji dorosłych}

Ze względu na nieustanny rozwój technologiczny żyjemy w społeczeństwie, które wymaga od swoich członków ciągłego zdobywania nowej wiedzy. Świat ciągle zmienia się, w związku z czym wiedza zdobyta kiedyś nie wystarcza tak, jak było to $\mathrm{w}$ kulturach postfiguratywnych ${ }^{7}$ (wiedza była przekazywana młodym przez przedstawicieli starszych pokoleń). Ciągłe uczenie się i aktualizowanie wiedzy to coś codziennego i koniecznego.

Uczenie się to najbardziej uniwersalny, codzienny proces, zachodzący od narodzin do śmierci. Jak zostało powiedziane to wcześniej, ze względu na swoje osadzenie w kulturze, ważne jest dla rozwoju jednostek i ewolucji gatunku. Najczęściej utożsamia się je z sytuacją, w której ktoś komuś przekazuje wiedzę do opanowania. Naukowo definiuje się je natomiast jako

zintegrowany proces składający się z dwóch powiązanych ze sobą procesów składowych, które wzajemnie na siebie oddziałują: 1. to proces interakcji (pośrednich lub bezpośrednich) między uczącym się a jego otoczeniem oraz 2. psychiczne procesy przyswajania i przetwarzania wiedzy, które prowadzą do rezultatów uczenia się̨8.

Edukacją dorosłych zajmuje się andragogika. Jednym z pierwszych obszarów uczenia się dorosłych opisanych przez andragogikę jest edukacja formalna, czyli edukacja instytucjonalna, której poszczególne etapy zwieńczane są dyplomami i świadectwami umożliwiającymi selekcję do ról społecznych. Idea edukacji ustawicznej (lifelong education) zyskała popularność w 1949 roku dzięki wierze ekonomistów w możliwość pomnażania potencjału ludzkiego, a co za tym idzie - zwiększenie wydajności przedsiębiorstw oraz wzrostu społecznego za pomocą wiedzy. Motywacją była także wiara, że dzięki wiedzy ukształtuje się społeczeństwo obywatelskie 9 . Ten model nauczania określa się jako technologiczny; za organizację procesu edukacyjnego i realizację misji społecznej (krzewienia wiedzy obiektywnej) odpowiedzial-

\footnotetext{
${ }^{6}$ M. Malewski, Modele pracy edukacyjnej z ludźmi dorostymi, Teraźniejszość - Człowiek Edukacja, 2000, 1, s. 53.

${ }^{7}$ M. Mead, Kultura i tożsamość. Studium dystansu międzypokoleniowego, Warszawa 1978.

8 Z. Pietrasiński, Sztuka uczenia się, Warszawa 1964, s. 22-23.

${ }^{9}$ J. Kargul, Obszary pozaformalnej i nieformalnej edukacji dorostych. Przestanki do budowy teorii edukacji całożyciowej, Wrocław 2005, s. 36-39.
} 
ny jest nauczyciel. Uczestnicy procesu przyjmują postawę bierną wobec treści przekazywanych ${ }^{10}$.

Kiedy zaczęto wątpić w edukację formalną, w połowie XX wieku w Stanach Zjednoczonych Ameryki Północnej narodziła się edukacja pozaformalna. Była ona efektem docenienia znaczenia wiedzy zdobywanej poza formalnymi instytucjami; zauważono także, jak ważne jest środowisko społeczne: polityka i ludzie dużo bardziej wpływają na myślenie dorosłych niż przykłady z książek czy nakazane dyskusje $\mathrm{e}^{11}$.

To jednak nie zakończyło ewolucji myślenia o uczeniu się przez dorosłych. Zmiana ta (dotyczacca teorii i praktyki andragogicznej) to efekt tendencji dostosowawczych do zmian kulturowych ${ }^{12}$. Wyznacza się więc trzeci obszar edukacji dorosłych - edukację nieformalną. Definiuje się jako całożyciowy proces, podczas którego jednostka przyswaja postawy, wartości, umiejętności, wiedzę z powszedniego doświadczenia oraz zasobów i wpływów środowiska życia czy środków masowego przekazu - to twór pluralistyczny i rozmyty strukturalnie przenikający prawie wszystkie obszary funkcjonowania społeczeństwa. Treścią jest wiedza prawd społecznie wytwarzanych. Proces uczenia się jest tak naturalny, że często niezauważany, więc nie traktowany jako taki ${ }^{13}$. Mówi o tym Étienne Wenger:

A gdyby przyjąć (...) perspektywę, taką, która sytuuje uczenie się w kontekście naszego życiowego doświadczenia wynikającego z uczestnictwa w świecie? A gdyby założyć, że uczenie się jest w znacznej mierze częścią naszej ludzkiej natury, tak jak jedzenie czy spanie, że jest zarówno czynnikiem podtrzymania życia, jak i czymś nieuniknionym, a także, mając szanse uczenia się - jesteśmy w tym zupełnie dobrzy. I co, jeżeli na dodatek przyjąć, że uczenie się jest w swej istocie fundamentalnym zjawiskiem społecznym odzwierciedlającym naszą głębszą naturę społeczną jako istot ludzkich, zdolnych do poznawania? ${ }^{14}$.

Celem tego rodzaju edukacji nie jest zdobywanie wiedzy samej w sobie, ale budowanie pod jej wpływem lepszego, bardziej świadomego i podmiotowego życia, bycia w świecie, wynoszenie z enklaw nędzy czy bezrobocia, emancypacja. Poszukiwanie wiedzy to zadanie uczącego się dorosłego. Metodą tego typu edukacji jest dialog; brak jej sztywnych reguł nauczania ${ }^{15}$. Edukacja cechuje się kontekstualną refleksyjnością, na którą składają się liczne

${ }^{10}$ M. Malewski, W poszukiwaniu teorii uczenia się ludzi dorostych, Teraźniejszość - Człowiek - Edukacja, 2006, 2, s. 49.

${ }^{11}$ J. Kargul, Obszary pozaformalnej i nieformalnej edukacji dorostych, s. 39.

12 M. Podgórny, Coaching - nowa przestrzeń edukacji dorostych, [w:] Kultura jako przestrzeń edukacyjna, s. 64 .

${ }_{13}$ M. Malewski, W poszukiwaniu teorii uczenia się, s. 57.

${ }^{14}$ R. Wenger, [cyt. za:] Tamże, s. 43.

${ }^{15}$ Tamże, s. 56-57. 
konteksty kulturowe, determinujące proces i czynności edukacyjne ${ }^{16}$. Tłem dzisiejszej edukacji dorosłych są zachodzące procesy i zmiany w obrębie społeczeństwa ponowoczesnego ${ }^{17}$.

Marek Podgórny zauważa, że zadaniem andragogów jest podejmowanie wysiłku pozwalającego uniknąć sytuacji, w której dystans między rzeczywistością kulturową a edukacyjną będzie się powiększał ${ }^{18}$. Dlatego, teoria edukacji dorosłych od lat bada obszary edukacji nieformalnej.

Należy dodać jeszcze, że w nieformalnym uczeniu się (ale nie tylko w zasadzie te warunki uczenia się dotyczą każdej sytuacji edukacyjnej) istnieją swoiste wymiary zdobywania wiedzy. Pisze o tym Knud Illeris ${ }^{19}$. Uważa, że to treść (praktyczna lub teoretyczna) - jej przyswojenie stanowi proces kognitywny. Drugi aspekt to emocje: uczenie się jest procesem emocjonalnym (psychologia mówi o procesie psychodynamicznym, czyli obejmującym energię psychiczną transmitowaną przez uczucia, postawy i motywacje). Emocje mobilizują uczenie się, a jednocześnie uczenie się ma na nie wpływ i może je kształtować. Nie są to chwilowe stany emocjonalne - związane są z postawą uczącego się wobec procesu uczenia się. Należy rozpatrywać je jako emocje wobec procesu poznawania, na przykład uczenie się w szkole jest związane z postawą uczącego się wobec przedmiotu, nauczyciela, konkretnej szkoły, ale też ogólnie wobec instytucji edukacyjnej ${ }^{20}$. Po trzecie, uczenie to proces społeczny, który zachodzi w interakcjach między jednostką a jej otoczeniem, przez co, ostatecznie, zależny jest od warunków społecznych i historycznych ${ }^{21}$.

Istotne $\mathrm{w}$ zdobywaniu wiedzy są warunki zewnętrzne - przestrzenie, w jakich zachodzi. Wyróżnia się: uczenie się z codzienności, uczenie się przez praktykę, uczenie się w szkołach oraz innych instytucjach edukacyjnych, uczenie się $\mathrm{w}$ miejscu pracy i uczenie się zespołowe. Sytuacje uczenia się i ramy, w których zachodzi, wpływają na jego efekty ${ }^{22}$.

Potencjał edukacyjny eventów należy rozpatrywać w ramach uczenia się z codzienności. Zachodzi bez planowania, przypadkowo, podczas poruszania się w różnych sferach życia bez intencji uczenia się czegokolwiek.

${ }^{16}$ M. Pryszmont-Ciesielska, (Nie)uchwytne mikroświaty uczacych się dorostych - ujęcie teoretyczno-metodologiczne, [w:] Kultura jako przestrzeń edukacyjna, s. 28.

${ }_{17}$ M. Malewski, za: M. Pryszmont-Ciesielska, (Nie)uchwytne mikroświaty uczacych się dorostych, s. 28.

${ }^{18}$ M. Podgórny, Coaching - nowa przestrzeń edukacji dorostych, [w:] Kultura jako przestrzeń edukacyjna, s. 64.

${ }_{19}$ K. Illeris, Trzy wymiary uczenia się. Poznawcze, emocjonalne i społeczne ramy wspótczesnej teorii uczenia się, przekł A. Jurgiel, red. M. Malewski, Wrocław 2006.

${ }^{20}$ Tamże, s. 188.

${ }^{21}$ Tamże, s. 24-45.

${ }^{22}$ Tamże, s. 188. 


\section{Od społeczeństwa agrarnego do konsumpcyjnego}

Truizmem będzie stwierdzenie, że współczesny świat różni się w sposób znaczący od tego przed wiekami. W wielu teoriach opisujących ewolucję cywilizacji powtarza się przekonanie, że rozwój techniki i postęp związany z komputeryzacją to kluczowe elementy tworzące nowe społeczeństwo. Jedną z najbardziej znaczących jest wizja Alvina Tofflera ${ }^{23}$. Mówi on o trzech erach istnienia świata: agrarnej, przemysłowej oraz związanej z rozwojem technologii i przepływu informacji. Era rolnicza trwała tysiące lat i obejmowała wszystkie cywilizacje ziemskie. $W$ jej trakcie utrzymywano się z uprawy roli - producent był jednocześnie konsumentem wytworzonych dóbr. Era druga - cywilizacja przemysłowa - trwała trzysta lat. Nastała w wyniku rewolucji przemysłowej, której skutkiem był podział na konsumentów i producentów, a znaczną część żywności, towarów i usług zaczęto przeznaczać na sprzedaż lub do wymiany. Podstawę ery trzeciej, postindustrialnej, stanowią zróżnicowane i odnawialne źródła energii.

Drugą istotną różnicą między erami jest sposób archiwizowania informacji i ich przekazywania. W pierwszej erze wiedza żyła długo i była przechowywana przez starszyznę plemienną. W erze kolejnej powstały: oświata, muzea i biblioteki, a dane zaczęto zapisywać. $W$ trzeciej fali narodziła się technicyzacja i dała większe możliwości przechowywania wiedzy ${ }^{24}$ - skutkiem tego jest zwiększona szybkość dostępu do informacji.

W erze przemysłowej rozwijano metody produkcji, bo uważno, że podnoszenie jej poziomu zapewni pełne zatrudnienie i stabilność gospodarczą. Produkcja uważana była za działanie na rzecz społeczności (społeczeństwa produkcyjnego), a konsumpcję jeszcze pod koniec XIX wieku traktowano jako proces wtórny do niej i kojarzono z czymś prywatnym oraz destrukcyjnym. Jednak nieustanne ulepszanie technologii prowadziło do nadwyżek produkcji, pojawiały się też nowsze i tańsze metody dystrybucji ${ }^{25}$. W Ameryce i Europie Zachodniej konsumpcja towarów stopniowo narastała, aż przekształciła się w aktywność mającą na celu podniesienie standardu życia. Pojawiło się społeczeństwo konsumpcyjne, czyli takie, w którym posiadanie (szczególnie tego co nowe, wzbogacone o dotychczas nieistniejące funkcje) zaczęło decydować o prestiżu społecznym ${ }^{26}$ i utrzymaniu "dystansu społecznego" w stosunku do przedstawicieli niższych klas ${ }^{27}$.

${ }^{23}$ A. Toffler, Trzecia fala, przekł. E. Woydyłło, Warszawa 1997.

${ }^{24}$ Tamże, s. 81-83, 217, 277.

${ }^{25}$ G. Makowski, Światynie konsumpcji. Geneza i społeczne znaczenie centrum handlowego, Warszawa 2003, s. 25-27.

${ }^{26}$ J.K. Galbraith, Społeczeństwo dobrobytu, państwo przemysłowe, przekł. J. Prokopiuk, Z. Zinserling, Warszawa 1973, s. 118.

${ }^{27}$ Z. Melosik, Postmodernistyczne kontrowersje wokót edukacji, Torun - Poznań 1995, s. 200. 
Konsumpcja najpełniej realizuje się w galerii handlowej, która jest uznawana za instytucję społeczeństwa konsumpcyjnego. Zakupy stanowią najwyższą formę aktywności kulturowej, a dzięki wizytom w centrach handlowych klienci budują własną tożsamość oraz nowe więzi społeczne ${ }^{28}$.

\section{Handel jako element kultury}

Nazwa „galeria handlowa" przywołuje skojarzenie z galerią sztuki i sugeruje, że miejsce oraz towary w nim dostępne są ekskluzywne i wyjątkowe. Jest to efekt swoistej rewolucji handlowej. Jednak wymiana dóbr materialnych oraz ich przepływ ze strefy produkcji do strefy konsumpcji nie są wynalazkami postmodernizmu. Na ziemiach polskich handel rodził się wraz z zachodzącymi w społeczeństwie przekształceniami: im bardziej społeczeństwo przestawało być samowystarczalne, im bardziej odchodziło od agrarności, tym większe stawało się zapotrzebowanie na produkty, które można kupić.

Wymianę handlową praktykowano już w neolicie ${ }^{29}$ - początkowo zajmowali się tym sami zainteresowani. Stopniowo pojawiali się pośrednicy i pieniądze. W średniowieczu sprzedawano na targach i w karczmach, wtedy też narodził się zawód kupca. W XVI i XVII wieku powstały jarmarki - handel odbywał się w wyznaczone dni tygodnia. Sprzedaż codzienna pojawiła się dopiero w połowie XIX wieku i wtedy też powstały pierwsze sklepy, które początkowo nie zajmowały dużej powierzchni ${ }^{30}$, a dopiero z czasem stały się wieloizbowe i wielobranżowe ${ }^{31}$. Następnym krokiem rozwoju instytucji handlowych były narodziny domów handlowych (XIX-XX w.), które istotnie przyczyniły się do wzrostu konsumpcji i głębokich przemian jej charakteru ${ }^{32}$.

Poprzednicy galerii handlowych - pasaże pojawiły się początku XIX wieku. Były to przykryte dachami (często szklanymi) przejścia na poziomie chodnika, które łączyły budynki lub ulice. Mieściły się w nich wejścia do przyległych sklepów. Przykładem takiego pasażu może być powstała w 1860 roku w Milanie Galleria Vittorio Emanuele II. Eklektyczne budynki istniejące do dziś wyglądają jak autentyczne kamienice z połowy XIX wieku, a ustawienie ich $\mathrm{w}$ pierzejach daje wrażenie prawdziwej ulicy. Jedyna różnica to szklany dach na żelaznej konstrukcji zwieńczony kilkoma kopułami.

${ }^{28}$ J. Fiske, [cyt. za:] G. Makowski, Światynie konsumpcji, s. 64.

${ }^{29}$ Historię handlu opracowano na podstawie: H. Samsonowicz, Z. Landau Z., handel [hasło w:] Encyklopedia historii gospodarczej Polski do 1945 roku, t. 1 A - N, red. A. Mączaka, Warszawa 1981, s. 225-247.

${ }^{30}$ Historia kultury materialnej Polski w zarysie, tom VI, Od 1870 do 1918, red. B. Baranowski, J. Bartyś, T. Sobczak, Wrocław 1979, s. 346-348.

${ }^{31}$ Tamże, s. 343.

${ }^{32}$ G. Makowski, Świątynie konsumpcji, s. 21. 
Obecnie, po niemal trzydziestu latach istnienia wolnego rynku, wyróżnia się następujące podstawowe typy sklepów sprzedaży detalicznej3: sklepy o niedużej powierzchni i z rozwiniętą obsługą - każdy towar podawany jest przez sprzedawcę; powszechne sklepy samoobsługowe (klient może samodzielnie oglądać produkty i je wybierać). Zalicza się do nich między innymi: samy i supersamy (supermarkety), sklepy dyskontowe o zaniżonym standardzie i sklepy typu up-to-scale (standard zawyżony) ${ }^{34}$. Do tej klasyfikacji warto dodać convience shop: sklepy położone niedaleko osiedli mieszkaniowych lub w innych miejscach dogodnych dla handlu, otwarte długo; można kupić w nich towary podstawowe (np.,,Żabka”, sklepy na stacjach benzynowych) ${ }^{35}$.

Kolejnym typem są uniwersalne wielkopowierzchniowe sklepy samoobsługowe (hipermarkety, supermarkety; powyżej 1500 m²). Znaleźć w nich można tańsze i droższe odpowiedniki tych samych produktów niemal wszystkich branż. Ostatnim rodzajem są domy towarowe i handlowe - miejsca nastawione na zakupy robione dla przyjemności, $\mathrm{w}$ których sprzedawane są towary ekskluzywne. Asortyment jest szeroki, a poziom usług - rozwinięty. Zajmują budynki wielokondygnacyjne $w$ centrach miast ${ }^{36}$. W definicję tę wpisują się galerie (centra) handlowe. Ponieważ jednak pojęciem tym (centrum handlowe) określa się też centra usytuowane na peryferiach mias ${ }^{37}$, umieszczane $w$ budynkach jednokondygnacyjnych, należałoby zapewne nieco ją zmodyfikować, wyróżniając domy handlowe $\mathrm{w}$ centrach miast i peryferyjne. Istotną różnicą między nimi jest powierzchnia samoobsługowego sklepu spożywczego - znacznie większa na peryferiach niż w przypadku śródmiejskich domów handlowych.

Galerie handlowe w obecnym rozumieniu narodziły się w Stanach Zjednoczonych. Tam w 1896 roku w USA w Baltimore otwarto Roland Park Shopping Center, a w Maryland - pasaż handlowy ze sklepami różnych branż. Pierwsze centrum w Ameryce to Market Square (1916 r.) w Lake Forest w Ilinois w stanie Chicago ${ }^{38}$. Na Starym Kontynencie pojawiły się około lat 60 . XX wieku, a rozkwit datuje się na lata 80. Do Polski trafiły w 1995 roku, kiedy to pierwsze centrum handlowe wybudował koncern IKEA w Jankach koło Warszawy $^{39}$.

${ }^{33}$ Należy zauważyć, że w ostatnich czasach rozwinęła się także sprzedaż internetowa: klienci mogą kupować zarówno w sklepach, które nie mają swoich siedzib, jak też w hipermarketach czy księgarniach internetowych. Można zamówić dostawę pod wskazany adres.

${ }^{34}$ J. Chwałek, Nowoczesny sklep, Warszawa 1993, s. 51-52.

${ }^{35}$ Convenience store [hasło w:] Wikipedia. Wolna encyklopedia, https://pl.wikipedia.org/ wiki/Convenience_store [data dostępu: 13.05.2017].

${ }^{36}$ Typy sklepów za: J. Chwałek, Nowoczesny sklep, s. 51-52, 119-137.

37 A. Szromnik, dom towarowy, [hasło w:] Leksykon marketingu, red. J. Alktorn, T. Kramer, Warszawa 1998, s. 64; G. Makowski, Świątynie konsumpcji, s. 90.

${ }^{38}$ G. Ritzer, Magiczny świat konsumpcji, przekł. L. Stawowy, Warszawa 2001, s. $29-30$.

${ }^{39}$ G. Makowski, Świątynie konsumpcji, s. 52-53 i 57. 


\section{Galeria handlowa jako fenomen kultury współczesnej}

Malle na całym świecie budowane są według podobnej zasady - na wzór pierwszego domu handlowego Northland Shopping Center, który powstał w Edina w stanie Minnesota w 1954 roku. Zaprojektowany został przez austriackiego architekta Victora Gruena ${ }^{40}$. Założeniem było stworzenie idealnego miasta $\mathrm{w}$ mieście ${ }^{41}$. Dlatego właśnie shopping mall to nie tylko budynek, w środku którego znajdują się sklepy. Są tam ławeczki, latarnie, klomby, wodospady. Można - jak na rynku - załatwić sprawę w banku ${ }^{42}$ i na poczcie, czy zjeść lody w cukierni, czytając książkę. Jednak środku jest zawsze ciepło, czysto i ładnie pachnie (zgodnie z zasadami marketingu sensorycznego ${ }^{43}$.

Dla współczesnych domów handlowych (śródmiejskich i peryferyjnych) wspólne są: część handlowa, część rozrywkowa (kino, miejsce zabaw dla dzieci, niekiedy dyskoteka, bilard, czy pub; bywają nawet boiska do piłki nożnej, lasy deszczowe (sic!), kaplice ślubne, sale koncertowe, SPA, kręgielnie, kluby nocne $\left.{ }^{44}\right)$, food court (skupisko barów szybkiej obsługi oraz miejsce spotkań) i alejki, wzdłuż których umieszczone są sklepy ${ }^{45}$.

Powiedzieć, że stanowią element kultury, to mało. Śmiało można nazwać je fenomenem. Choć na całym świecie już zauważa się ich upadek, w Polsce wciąż są symbolem luksusu, na który nie każdy może sobie pozwolić. Przyniosły dużo zmian: społecznych, gospodarczych i związanych ze strukturą miasta.

Handel w niedzielę przyzwyczaił społeczeństwo do wygody robienia zakupów niemal zawsze i wywołał strach osób, którym na sercu leży dobro rodziny: że zamiast korzystać z dobrodziejstw natury, społeczeństwo będzie spędzać czas w sklepach. Ciepła, bezpieczna przestrzeń w centrum miasta sprawia, że chętnie pracują tu freelancerzy - osoby, które nie zdecydowały się na pracę $\mathrm{w}$ żadnej instytucji czy przedsiębiorstwie i utrzymują się z wykonywania zleceń, a nie mają własnych biur. Jednocześnie galerie negatywnie

40 Tamże, s. 97.

41 T. Gujska-Szczepańska, Wszystko o galeriach handlowych i supermarketach. Wywiad z Krystynq Słowik, http://bibulamilanowska.eu/index.php/ludzie/749-wszystko-o-galeriach-handlowych-i-supermarketach-wywiad-z-krystyna-slowik, [data dostępu: 29.04.2017].

42 Do tego stopnia, że w USA, w stanie Waszyngton w galerii umieszczono... ratusz miejski, a projekt nazwano „Town Hall in the Mall”, zob. G. Makowski, Światynie konsumpcji, s. 53.

${ }^{43}$ D. Goldman, Jak pachna polskie sklepy, http://www.olfaktoria.pl/2014/09/jak-pachna-polskie-sklepy/ [data dostępu: 1.05.2017].

44 Powierzchnia jednego z większych centrów handlowych - New South China Mall - wynosi 999000 m2 i swym wyglądem nawiązuje do wielu geograficznych krajobrazów, jak np. do Wenecji (są tu kanały), Egiptu, czy Paryża. Kręcone są w nim filmy. Jednakże, dokumentalistów nie przyciągają pełne sklepy, a puste alejki, ponieważ z 2400 planowanych sklepów wynajęto zaledwie kilkadziesiąt.

${ }^{45}$ G. Makowski, Świątynie konsumpcji, s. 90-94. 
wpłynęły na drobny handel, a wynajem powierzchni w nich nie należy do tanich (z tego powodu najemcy nazywają się "galernikami", przyrównując się do więźniów na dawnych statkach).

Ich pojawienie się zmieniło strukturę miast: wraz $\mathrm{z}$ nimi zbudowano nowe drogi; powstały specjalne linie autobusowe dla klientów centrów handlowych (szczególnie tych usytuowanych na peryferiach), przekształcono nazwy przystanków (przed wybudowaniem Galerii Dominikańskiej we Wrocławiu autobusy zatrzymywały się przy Placu Dominikańskim, teraz przystanki nazywają się tak, jak galeria). Ich bryły (mniej lub bardziej udane) wpłynęły na krajobraz. W ostatnim czasie także wiele galerii powstaje blisko węzłów kolejowych - budynek mallu jest połączony z dworcem (które w Polsce często są zaniedbane i niebezpieczne). To zapewnia klientów i podnosi bezpieczeństwo okolicy.

Istnieją przypadki, w których powstanie galerii wpłynęło pozytywnie na środowisko społeczne ${ }^{46}$. Taką rolę spełniła Galeria Mokotów w fabrycznej części Mokotowa. Dzielnica ta pozbawiona była przestrzeni publicznej. Po otwarciu, w mallu zaczęły czas spędzać starsze osoby: siadały na ławkach i patrzyły na innych, i dzieci traktujące miejsce jako substytut podwórka. Nie tylko: pojawili się także drobni złodzieje i młodociane prostytutki, tak zwane galerianki ${ }^{47}$. Takie grupy istnieją $\mathrm{w}$ większości galerii.

Ciekawe jest, że w świadomości społecznej miasto bywa kojarzone z przestrzenią handlu. Kiedy w Krośnie przeprowadzono konkurs dla dzieci pod tytułem „Moje miasto”, dzieci z miasta przysyłały rysunki z zaznaczonymi głównie kościołami, a dzieci z okolicznych wiosek - z marketami i kantorami ${ }^{48}$.

Malli w miastach można zaobserwować więcej i są coraz większe ${ }^{49}$. Jest w nich coś kuszącego, ale też coś, co się krytykuje. Mówi się o nich „świątynie konsumpcji". Pojęcie to po raz pierwszy zostało użyte już ponad sto

${ }^{46} \mathrm{~W}$ tym kontekście ciekawa jest konstatacja architektki Krystyny Słowik, która mówi o roli pierwszych McDonaldów. Jej zdaniem, służyły one szczególnie młodym ludziom jako swoiste schronienie przed bylejakością na zewnątrz. Mówi też o roli, jaką odegrały toalety w sieci restauracji. Jako pierwsze były bezpłatne i dostępne dla każdego. Ich wysoki standard wpłynął na zmianę wyglądu toalet publicznych w Polsce; por. T. Gujska-Szczepańska, Wszystko o galeriach handlowych.

${ }^{47}$ K. Słowik cytuje G. Makowskiego, por. Tamże.

${ }^{48}$ K. Chrzanowska, [cyt. za:] R. Sulima, Antropologia codzienności, Kraków 2000, s. 145.

49 Powierzchnia największych polskich galerii handlowych (Arkadii w Warszawie i Manufaktury w Łodzi) wynosi $110000 \mathrm{~m} 2$, niewiele mniejsza jest plasująca się na 3. miejscu pod względem powierzchni handlowej Posnania w Poznaniu (powierzchnia handlowa 101000 m2, a całkowita: 9 ha). A i tak te centra są niewielkie w porównaniu z Dubai Mall, którego powierzchnia wynosi 112,4 ha. Obok sklepów, kawiarni i restauracji jest tam akwarium o pojemności 10 mln litrów wody, w którym pływa ponad 33 tysiące okazów zwierząt morskich, w tym 400 rekinów. Jest też lodowisko. 
lat temu $\mathrm{u}^{50} \mathrm{w}$ odniesieniu do dziewiętnastowiecznych domów towarowych. Metafora wzięła się z bogactwa oferowanych produktów oraz że wykorzystywano święta do zwiększenia sprzedaży. W Paryżu właściciel jednego z domów towarowych zatrudnił organistę z katedry Notre Dame do grania na organach zamontowanych $\mathrm{w}$ sklepie, a dom towarowy w Chicago reklamowano jako „katedrę wszystkich domów towarowych na świecie” ${ }^{51}$. Śpiewały w nich chóry i ustawiano tam piękne szopki. Klienci dziękowali dyrekcji, że dzięki dekoracjom mogli „poczuć obecność Pana Jezusa” ${ }^{52}$. Łączenie sfer sacrum i profanum nie jest nowe - od średniowiecza urządzano przy parafiach odpusty i targi. Jednak centra handlowe posługują się inną perspektywą: to nie "przy okazji" świąt urządza się targ, ale święta wykorzystuje dla handlu ${ }^{53}$.

Porównanie miejsca handlu z miejscem kultu może zaskakiwać lub oburzać, jednak galeria handlowa uważana jest za instytucję społeczeństwa konsumpcyjnego: stanowi rodzaj struktury społecznej, składającej się ze zobiektywizowanych, powszechnych i akceptowanych wzorów działania, na straży których stoją normy ${ }^{54}$. To tu zaspokajane są potrzeby wypływające $\mathrm{z}$ norm społeczeństwa konsumpcyjnego (osiągnięcie lub zachowanie odpowiedniego statusu społecznego poprzez odpowiednią liczbę zaświadczających o tym dóbr).

\section{Wymiar edukacyjny eventu}

Aby odpowiedzieć na pytanie o edukacyjny wymiar eventów (wydarzeń kulturalnych organizowanych w galeriach handlowych): w jaki sposób mogą uczyć czegoś, przeprowadzono badania terenowe wśród ich uczestników w dwóch wrocławskich galeriach handlowych - Galerii Dominikańskiej55 i Pasażu Grunwaldzkim ${ }^{56}$ (teren badań), podczas trzech eventów.

Autorka artykułu zdecydowała się na badania jakościowe, które wywodzą się z humanistycznej tradycji nauk społecznych. Zaczynają się tam, gdzie

${ }^{50}$ K. Romanowska, A. Więcka, Połknięci przez mall, „Newsweek”, 2001, 7, s. 82.

51 Tamże.

52 G. Makowski, Świątynie konsumpcji, s. 62.

53 R. Sulima, Antropologia codzienności, s. 175-183.

54 J.H. Turner, [cyt. za:] G. Makowski, Świątynie konsumpcji, s. 61.

55 Galeria Dominikańska usytuowana jest przy jednej z głównych arterii komunikacyjnych miasta, w pobliżu kościoła św. Wojciecha, należącego do zakonu dominikanów. To pierwszy wrocławski shopping mall. Wybudowano ją w 2001 r. Zajmuje trzy kondygnacje i znajduje się w niej ponad 100 sklepów oraz lokali gastronomicznych, natomiast nie ma (wyjątkowo) kina, ani innych obiektów rozrywkowych, a powierzchnia sięga około 30 tys. m2.

56 Pasaż Grunwaldzki znajduje się w centrum miasta - przy Rondzie Reagana (dawniej ta część miasta zwana była Placem Grunwaldzkim, stąd nazwa). 130000 m2 wynajmowanej powierzchni zajmuje ponad 200 sklepów, kino, liczne kawiarnie i restauracje. Otwarty został 4 kwietnia 2007 r. 
zaczyna się rzeczywistość społeczna w postaci, jaką nadają jej ludzie; prowadzi się je na postawie doświadczenia potocznego. $W$ jego ramach zbiera się teksty - ich sensy pochodzą z sytuacji, w której teksty zostały wytworzone ${ }^{57}$. Ponieważ badany ma mieć szansę wypowiedzenia się, a badacz nie musi zaprzeczać własnym wartościom, jest w nie wpisana zgoda na brak obiektywizmu ${ }^{58}$. Spośród różnych rodzajów badań wybrano badanie etnograficzne, które uznano za najbardziej trafne. Pozwala ono na wszechstronny opis sposobu życia wybranej grupy ze wszystkimi kulturowymi aspektami ${ }^{59}$. Wymaga wejścia w daną grupę i poznania jej (język, zwyczaje, zachowania, sposoby myślenia) oraz przyjęcia punktu widzenia obserwowanych. Badania tego rodzaju prowadzone są $\mathrm{w}$ środowisku naturalnym i wykorzystują takie metody zbierania materiałów, jak: obserwacja, wywiad (nieskategoryzowany i otwarty, przyjmuje czasem formę niedokończonych rozmów) oraz analiza wytworów ludzkich ${ }^{60}$. Sedno stanowi obserwacja uczestnicząca. Wybór uzasadniony był specyfiką tematu oraz świadomością, że szeroką wiedzę na badany temat można zdobyć jedynie przez uczestnictwo i kontakt ze zjawiskiem.

Taka obserwacja odbyła się podczas trzech wydarzeń: „Stulecie Robotów” (Galeria Dominikańska), , ,Bike Story” (Galeria Dominikańska) i „ZZadbaj o swoje serce - Bezpłatne badania EKG oraz bezpłatna konsultacja kardiologiczna" (Pasaż Grunwaldzki). Wywiady przeprowadzono z sześcioma osobami.

W następnej części artykułu najpierw zostaną przedstawione opisy eventów, a następnie wnioski z obserwacji i rozmów (odpowiedź na problemy szczegółowe).

\section{"Stulecie Robotów"}

W ramach eventu zorganizowano:

- Wystawę pokazującą pierwszych twórców techniki i urządzeń mechanicznych, pierwsze narzędzia do zapisu dźwięku - wszystko to uzupełniono informacjami o robotach $\mathrm{w}$ literaturze i filmie; poza tym: ewolucja różnego rodzaju baz danych, wykorzystywanie robotów w przemyśle współczesnym, historia wyścigu kosmicznego między ZSRR a USA, tendencje w robotyce i plany jej rozwoju.

- Wystawę dziecięcych gier planszowych inspirowanych techniką.

- Warsztaty projektowania, które dawały możliwość zaprojektowania i zaprogramowania własnego robota (minisumo).

${ }^{57}$ K. Konarzewski, Jak uprawiać badania oświatowe. Metodologia praktyczna, Warszawa 2000, s. 26.

${ }^{58}$ Tamże, s. 25.

59 T. Pilch, T. Bauman, Zasady badań pedagogicznych. Strategie ilościowe i jakościowe, Warszawa 2001, s. 294.

60 Tamże, s. 295. 
Po wystawie oprowadzał oryginalny przewodnik - mówiący humanoidalny robot, na ekranie którego można było przeczytać informacje o ekspozycji oraz poznać historię robotów.

\section{"Bike Story"}

Tematem eventu były rowery. $\mathrm{W}$ jego ramach zorganizowano:

- Trwającą osiem dni wystawę ukazującą rowery z różnych stron świata (Indie, Włochy, Anglia, Polska) oraz różne ich zastosowania (wojskowe, rower używany przez Kazimierza Nowaka w podróży po Afryce, pocztowe, damskie, męskie, do sportów ekstremalnych).

- Wystawę dotycząca książki: „Rowerem i pieszo przez Czarny Ląd” K. Nowaka.

- Prezentację Wrocławskiej Inicjatywy Rowerowej.

- Show (występ parateatralny) opowiadający historię pojazdu: pierwsze modele rowerów; nazwiska twórców, prezentowano jazdę na bicyklach, odbył się pokaz mody cyklistów.

- Pokaz "Jak naprawić własny rower".

- Konkurs na jak najszybsze złożenie roweru.

- Jazdę na trenażerach.

- Znakowanie rowerów (akcja policyjna).

- Spotkanie ze znanymi cyklistami (Ryszard Szurkowski, Bolesław Krawczyk).

\section{„Zadbaj o swoje serce}

- Bezpłatne badania EKG oraz bezpłatna konsultacja kardiologiczna"

Wydarzenie poświęcono konieczności dbania o serce i świadomości zdrowotnej. Zorganizowano darmowe badanie EKG, poprzedzone rejestracją oraz indywidualną rozmową na temat nawyków zdrowotnych, wyliczeniem wskaźnika BMI, pomiarem ciśnienia oraz zakończone konsultacją z kardiologiem, który radził, jak należy się odżywiać, jakie leki zażywać, jakie badania przeprowadzić dodatkowo i mówił o zależności między stylem życia a zdrowiem.

Jakiego rodzaju treść edukacyjną może nieść event:

umiejętności praktyczne, wiedza o świecie, wyzwalanie samoświadomości, wartości lub postawy?

\section{"Stulecie Robotów"}

Wydarzenie podzielono na sześć części: Historia robotów, Roboty przemystowe (pokazano m.in. robota wykonującego skrzypce), Roboty w kosmosie (m.in. model Łunochodu, opis wyścigu kosmicznego), Eksperymenty w robotyce (stoisko, na którym można było sterować gotowymi robotami lub zbudować 
i zaprogramować urządzenie według własnego pomysłu); Bionika (informacje o inspiracji tego działu robotyki naturą oraz o marzeniach człowieka, by stworzyć robot podobny do ludzi; można było zobaczyć m.in. dłoń precyzyjnie poruszającą palcami i głowę wodzącą "oczami” dookoła - to, co znajdowało się w polu widzenia "oczu” pokazywał pobliski ekran; był też krab uruchamiany przez umieszczenie ręki w odpowiednim miejscu), Wizje przyszłości (roboty osobiste i asystujące, mikroboty).

Dobrze przygotowana pod względem estetycznym ekspozycja pozwalała zdobyć informacje o otaczającym świecie: robotyka, komputeryzacja, historia (pokazano m.in. pierwsze metody przenoszenia danych). Zachęcała do nauki fizyki i chemii, mogła stanowić inspirację do podejmowania nauki w dziedzinie inżynierii. Uświadamiała także, jak bardzo cywilizacja zmieniła się pod wpływem rozwoju maszyn oraz że ta ewolucja wciąż trwa.

Wydarzenie miało wpływ na podnoszenie jakości życia: pozwalało przełamać technofobię ${ }^{61}$ (dotykającą szczególnie przedstawicieli starszych pokoleń) i wyzwalało myślenie o przyszłości. Umożliwiło także doświadczenie tego, co jest trudno dostępne (ekskluzywność doświadczenia). To potwierdza Ewa (podczas wywiadu opowiedziała o wystawie tropikalnych zwierząt w Galerii Dominikańskiej, ale to zdanie podkreśla, jak ważna dla niej była szansa uczestnictwa w zorganizowanym wydarzeniu): bo człowiek nie biega nigdzie, do ZOO rzadko kiedy, z pracy albo do pracy (...) (Ewa).

\section{"Bike Story"}

Wydarzenie przekazywało wiedzę o świecie zastanym (wiedza teoretyczna): umożliwiało poznanie historii rowerów i ukazywało kontekst kulturowy ich używania. Poszerzało zakres słownictwa ze względu na zastosowane profesjonalizmy: bicykl, welocyped, drezyna, riksza; zachęcało do czytania książek (wystawa o książce K. Nowaka, czytanie dzieciom opowieści „Afryka Kazika" napisanej na podstawie ww. książki).

Event był także zachętą do aktywności fizycznej (jazda na rowerze) i jazdy ekstremalnej (cyktoriale); pokazywał nowinki techniczne (trenażery). Poza tym, promował bezpieczną jazdę. Pozwalał zdobyć umiejętności praktyczne związane z użytkowaniem roweru.

Podobnie jak poprzednie wydarzenie, również i to było przygotowane w sposób wysoce estetyczny. Jak wspomniano wcześniej, obejmowało różne elementy i dzięki temu możliwe było przyswojenie dużej ilości trudno dostępnych informacji, co potwierdzają słowa Piotra: (...) podejrzewam, że sam z siebie, być może, nie szukatbym pewnie takich informacji, ale, jeżeli jest okazja zna-

${ }^{61}$ Inne eventy pozwalają przełamać pewne niepokoje: Ewa na wystawie zwierząt tropikalnych ww. galerii dotykała węża, przełamując strach przed nieznanym: (...) można było podejść i tam stał pan z wężem i każdy, kto chciał, mógł sobie zrobić zdjęcie z tym wężem [zdecydowałam się]... ja nie lubię śliskości (Ewa). 
leźć je, $i$ to jeszcze tak w pigułce, bo to w sumie na matej powierzchni, w krótkim czasie można się wiele dowiedzieć (Piotr).

Piotr zauważył, że takie wydarzenia motywują do zdobywania wiedzy: Pobudza (...) chęć zdobywania informacji jakichś, wiedzy, poszerza horyzonty. (...) Na takie wystawy robione rodzice zabieraja dzieci, dzieci widza, że można się czegoś nauczyć, czegoś więcej, czegoś ciekawego, co może być też dobra zabawa (Piotr).

\section{"Zadbaj o swoje serce"}

Badanie serca za pomocą elektrokardiogramu pozwalało na poszerzenie wiedzy o zdrowiu. Rozmowa z lekarzem i wręczane uczestnikom materiały edukacyjne przekazywały zasady zdrowego żywienia oraz informacje na temat prawidłowych norm ciśnienia. $\mathrm{W}$ rozmowie z lekarzem zdobywało się praktyczną umiejętność obliczania wskaźnika BMI.

Event pomógł w wyzwoleniu samoświadomości na temat stanu własnego zdrowia oraz sposobu dbania o nie, co potwierdza Bogusia: samokontrola dla siebie, dla swojej wiadomości: czy jestem obciążona, czy nie, genetycznie, także dużo dało mi to badanie (...), jakie badania mam zrobić, jakie leki mam brać, o, a nie biore (Bogusia).

Zorganizowanie badania $\mathrm{w}$ mallu pozwoliło na uniknięcie stresu związanego z wizytą $\mathrm{w}$ przychodni - można było w nim wziąć udział bez poczucia bycia chorym, co ma znaczący wpływ na jakość życia.

Ponieważ akcja została zorganizowana kolejny już raz (klienci biorą w nich udział regularnie): (...) wie pani, korzystam $z$ tych badań profilaktycznych piersi, tak samo, i (...) na następny rok, bo co dwa lata, robiłam... (Bogusia).

Działanie takie zwiększyło procent prowadzonych badań profilaktycznych $^{62}$ oraz dało szansę zmiany stylu życia badanych. To chyba jedno z najtrudniejszych zadań pedagogiki.

\section{Jakie środki stosowano $\mathrm{w}$ celu zachęcenia do udziału i przekazaniu treści edukacyjnej \\ (strona wizualna, nagrody, wywołanie emocji)?}

\section{"Stulecie Robotów"}

Wystawa była uporządkowana tematycznie. Eksponaty umieszczono w szklanych gablotach, były też plansze informacyjne (oprócz tekstu

${ }^{62}$ W wyniku badania EKG okazało się, że Bogusia ma chore serce i powinna zażywać leki. Gdyby nie badanie w galerii, nie wiedziałaby o tym: M.: A gdyby nie ta akcja tutaj - poszłaby pani do kardiologa tak normalnie, do przychodni?

B.: Tak mówiąc szczerze - chyba nie. Uważam, że tam jest za dużo czekania.

Organizator podczas rozmowy powiedział, że do około 5 osób wezwano tego dnia karetkę, bo badanie EKG wykazało stan przedzawałowy lub trwający od kilku godzin zawał. 
znajdowały się na nich ekrany z filmami). W dwóch przypadkach tematykę odzwierciedlał kształt stanowiska: jedno, odnoszące się do robotów kosmicznych, zostało ukryte $\mathrm{w}$ półokrągłym namiocie, $\mathrm{z}$ wnętrzem dachu ozdobionym gwiazdami; drugie, dotyczące bioniki, umieszczono pod zadaszeniem w kształcie wielkiego mechanicznego pająka o dużych świecących kolorowo oczach.

Część eksponatów mogła zostać wprawiona w ruch, na przykład przez przyłożenie ręki do specjalnego otworu lub przez naciśnięcie guzika. Można było zaprojektować własne roboty i zaprogramować je z użyciem specjalnych oprogramowań komputerowych, umożliwiono także sterowanie ruchem robotów za pomocą pilotów.

Dzięki zastosowanemu bogactwu środków przekazu i najnowszych rozwiązań technicznych, informacje docierały do odbiorców różnymi kanałami: można było czytać, oglądać, słuchać, dotykać. Część wiadomości była za trudna do odbioru przez dzieci. Mobilizowało to rodziców do szybkiego przyswojenia wiedzy tak, aby móc przekazać je pociechom.

\section{"Bike Story"}

- Podczas show o historii rowerów mężczyźni ubrani byli w stroje z XIX wieku (białe koszule z kołnierzykami, spodnie do połowy łydki, podkolanówki, szelki, kaszkiety na głowach) i na wielkich płachtach prezentowali ilustracje rowerów. Jeden z cyklistów głosił hasło: „Załóż kaszkiet, zapnij szelki, wskocz na bicykl - będziesz wielki".

- Stoiska z rowerami na wystawie były duże i kolorowe. Pokazywały rowery na tle plakatów ilustrujących miejsca, gdzie były lub są wykorzystywane; stoiska były ozdobione tak, by dekoracja kojarzyła się z rodzajem roweru: jeśli turystyczny, na podłodze rozsypano piasek, postawiono przyczepkę, rozłożono mapy; w przypadku rikszy scenografię tworzyły: zdjęcie z Indii (hinduska kobieta) oraz warzywa, owoce i naczynia z tego kraju ułożone na podłodze; rower wojskowy to zdjęcie lasu i gadżety służące do maskowania terenu i tym podobne. Rozmieszczone były na terenie całej galerii, każde stoisko eksponowało dwa rowery oraz zostało uzupełnione niebieską tabliczką z rysunkiem bicyklu, jego nazwą i opisem. Pokazano 14 pojazdów.

- Ponadto organizowano konkursy, w których do wygrania były: butelkowozielone T-shirty z nadrukiem roweru, odblaskowe opaski i kaski.

Wszystko było bardzo estetyczne, kolorowe. Wydarzenia odbywały się $\mathrm{w}$ całej galerii: wystawa na 1. piętrze (poziom +1$)$, spotkania $\mathrm{z}$ ważnymi osobami, trenażery, pokazy - na scenie na poziomie -1 .

Jednakże, przy podejmowaniu decyzji o udziale nie decydowały nagrody: Ciekawość. Tylko ciekawość.(...) Przede wszystkim treść. Takie dodatki ... [nagroda] To bytby tylko dodatek, jeżeli już (Piotr). 
Różnorodność form podawczych stanowiła dużą zachętę dla odbiorców, bo pozwalała odpowiedzieć na różne preferencje uczenia się: Liczę tylko na to, co gdzieś ustyszę, ewentualnie zobacze (Ewa). ... dla mnie opisy sa najciekawsze. Ja osobiście najwięcej pamiętam z tego, co przeczytam, więc to jest dla mnie ciekawe (Piotr).

\section{"Zadbaj o swoje serce"}

W przypadku badania EKG, bardziej niż strona estetyczna ważna była kwestia techniczna: jak $\mathrm{w}$ ruchliwym centrum handlowym przeprowadzić badania wymagające intymności. Dlatego, zbudowano stoiska osłonięte grubą tkaniną i zadbano o ich zadaszenie (badania odbywały się na parterze, a dach uniemożliwił klientom z wyższych pięter zaglądanie do środka). Niebieski kolor tkaniny osłaniającej uniemożliwiał przeoczenie punktu badawczego, a jej grubość tłumiła dźwięki z zewnątrz i wewnątrz.

Punkt badawczy umieszczono na parterze galerii, po przeciwnej stronie wejścia głównego (trzeba było obejść mniej więcej połowę Pasażu, aby dotrzeć do celu), na korytarzu, koło tak zwanej „Kolorowej fontanny”. Obecne były cztery lekarki: dwie udzielały konsultacji kardiologicznej, jedna prowadziła zapisy w rejestracji, kolejna wykonywała badania EKG. Uśmiechnięte, uważnie słuchały pacjentów, starały się ośmielać ich żartami lub życzliwymi słowami (niektórzy odczuwali strach przed badaniem).

Samo badanie i konsultacja były na tyle ważne i atrakcyjne (długi czas oczekiwania na badania w państwowych placówkach zdrowotnych), że nie musiano stosować specjalnych zachęt - przez cały czas trwania eventu do badań ustawiała się długa kolejka chętnych.

Każdy rejestrujący się otrzymywał: centymetr z barwnym oznaczeniem granic normy talii kobiecej i męskiej oraz ze skalą pozwalającą obliczyć poziom BMI, „Dzienniczek domowej samokontroli” dla cukrzyków do notowania poziomu cukru o różnych porach dnia, broszurki edukacyjne: „Dieta w zapobieganiu i leczeniu nadciśnienia tętniczego", "Jak dbać o swoje serce”.

Podsumowując, można powiedzieć, że metody wykorzystywane w celu zachęcenia klientów do udziału w wydarzeniach były różnorodne. Wśród nich należy wymienić wystawę, spotkanie z ekspertem (kolarz, lekarz, polityk, czy policjant), show (show rowerowe $\mathrm{z}$ akrobacjami na bicyklu i pokazem mody z epoki), prezentację (ilustrowany wykład o rowerach, pokazy jazdy na cyklotrialach), konkursy, działania praktyczne (budowanie własnego robota, obsługa wynalazków), uczenie się przez obserwację (instruktaż naprawy roweru). Eventy nie kuszą raczej nagrodami wysokiej wartości - jeśli już jakieś są, to raczej symboliczne (kaski dla rowerzystów, bawełniane T-shirty, opaski odblaskowe) i nie one decydują, że ktoś bierze udział w wydarzeniach: 
M.: Zachęcito panią właśnie to, że można wygrać nagrodę czy...

B.: Nie, tak po prostu mówiąc szczerze, to przechodziłam i znałam odpowiedź $i$ się zgłosiłam... (Bogusia).

Ważnym aspektem jest to, że można doświadczać wszystkiego za darmo i niekoniecznie mieć ku temu specjalne kwalifikacje.

Jakie reakcje wywołuje event, czy wywołuje interakcje między uczestnikami, jeśli tak, jakiego typu?

\section{"Stulecie Robotów"}

Uczestnikami byli głównie mężczyźni w różnym wieku. Kobietom towarzyszyły dzieci lub mężczyźni. Trudno określić liczbę zaangażowanych: każdy mógł podejść, obejrzeć jedną jej część przy okazji obecności w centrum.

Klienci oglądali wystawy, czytali informacje, robili fotografie, budowali własne roboty, wyjaśniali towarzyszom sposób działania różnorodnych mechanizmów. Często reagowano pozytywnie, a nawet entuzjastycznie; padały komentarze typu Fajne, fajne!, To się rusza. Dało się słyszeć wypowiedzi: Żeby to jeszcze w domu odkurzyło za ciebie; Tu jest dopiero robot, chodźcie!. Jeden z eksponatów na stoisku Bioniki, humanoid siedzący w fotelu, został skomentowany w następujący sposób: To robot, który zastępuje przy oglądaniu telewizji.

Rodzice tłumaczyli dzieciom mechanizm działania robotów i uczyli obsługi zabawek mechanicznych. Sami zapoznawali się z instrukcjami (anglojęzyczne), aby pomóc im w zabawie.

Osoby nie znające się, rzadko wzajemnie wymieniały uwagi. Kiedy jednak interakcja zachodziła, pytania dotyczyły zazwyczaj sposobu uruchomienia danego urządzenia lub rozmaitych ciekawostek.

Wiele osób robiło zdjęcia. Jedną z fotografujących była około 15-letnia uczennica. Zapytana, w jakim celu to robi, wyjaśniła, że nauczycielka fizyki dała możliwość podniesienia końcowej oceny z przedmiotu, pod warunkiem napisania referatu na temat eventu.

Nie wszystkich to, co działo się w galerii, interesowało.

\section{"Bike story"}

W evencie uczestniczyli klienci Galerii, nastolatki, rowerzyści, którzy zaplanowali w niej swoją obecność, rodzice z dziećmi, samotne kobiety, starsi mężczyźni, a także reporterzy radiowi. W konkursach udział brali głównie panowie ${ }^{63}$. Podobnie w jeździe na trenażerach udział wzięło zaledwie kilka kobiet.

\footnotetext{
${ }^{63}$ Wśród ośmiu osób próbujących swych sił w składaniu roweru była tylko jedna kobieta.
} 
Poszczególne atrakcje przyciągały grupy liczące od 10. osób (jazda na cyklotrialach) do 60. (spotkania, show, konkursy). Dużym zainteresowaniem cieszyła się akcja policji, natomiast zaledwie piątka dzieci przysłuchiwała się czytanej książce, a wystawę rowerową fragmentami oglądały osoby przypadkowe.

Ludzie oglądali wystawę, robili fotografie. Podczas spotkań zadawali pytania. Brali udział w konkursach i pokazach. Słuchali wypowiedzi i prosili o autografy. Event oglądany był przez osoby skupione wokół sceny na parterze budynku oraz przez klientów przebywających na wyższych piętrach.

Zaobserwowano moment poznania się różnych osób, jak na przykład kobiety i mężczyzny. Mężczyzna uśmiechnął się do stojącej w dużej odległości od niego kobiety, a kiedy ta odeszła od sceny, podszedł do niej. Dwaj starsi uczestnicy rozmawiali z badaczką; jeden z nich zdecydował się na przejażdżkę bicyklem, więc drugi mężczyzna i kobieta go dopingowali. Po niedługim czasie między mężczyznami rozpoczęła się rozmowa na różnorodne tematy. Okazało się, że poznali się na wystawie. Inny mężczyzna wykonał portret Szurkowskiego, a jeszcze inny robił notatki w czasie spotkania z nim.

Organizatorzy zachęcali do robienia fotografii, jazdy na rowerach, instruowali jak jeździć, pomagali utrzymać równowagę tym, którzy zdecydowali się spróbować swych sił na bicyklu.

Między uczestnikami panowała przyjazna atmosfera. Uśmiechano się do siebie przez scenę, wzajemnie namawiano do udziału w różnych atrakcjach. Uśmiech to oznaka zadowolenia, odprężenia, ale to także droga ku budowaniu pewnego rodzaju wspólnoty - wspólnoty śmiechu:

śmiech jest to cichy, społeczny kontakt (...), pewne porozumienie o społecznym świecie, w którym się znajdujemy. (...) Można się w tej sytuacji doszukiwać analogii do działań obrzędowych, zrozumiałych i ważnych dla określonej grupy, na przykład etnicznej, niezrozumiałych dla osób spoza owej wspólnoty ${ }^{64}$.

Zaistnienie tego rodzaju wspólnoty można traktować jako pierwszy impuls do budowania społeczności lokalnej.

\section{"Zadbaj o swoje serce"}

W badaniach uczestniczyło około 100 osób. Byli to zarówno ludzie starsi, jak i młodsi; głównie dorośli. Część z nich przyszła przypadkiem, inni - planowali swą obecność i wykonanie badania. Czekający w kolejce rozmawiali ze sobą o obawach, pytali się o wrażenia z badania. Rozmawiano także o sprawach dotyczących studiów i przyszłości, czy codzienności. Uczestnicy

${ }^{64}$ S. Critchley, [cyt. za:] A. Siemak-Tylikowska, Uczymy się społeczeństwa przez uśmiech, Kwartalnik Pedagogiczny, 2005, 3(197), s 102. 
wymieniali między sobą uwagi na temat organizacji, a z organizatorami rozmawiali o stanie zdrowia. Czytali ulotki i plakaty.

\section{Jak oceniana jest wartość eventów przez ich uczestników?}

Podobnie jak rozmaity może być ogół tematów poruszanych podczas eventów, tak różnorodna może być ich ocena przez uczestników i klientów galerii.

Kontinuum obejmuje oceny bardzo entuzjastyczne, jak ta poniższa:

Wiadomo, że nie u lekarza i tak... rozrywkowo, człowiek nie jest taki zestresowany, nie musi czekać w kolejkach, jeszcze do rejestracji; wszystko po kolei, łacznie z lekarzem, z konsultacja. Co za wspaniała rzecz (Bogusia).

Przez zdziwienie:

Raczej wszyscy robia zakupy a nie - przychodza ogladać jakieś show. (...) Ja tego trochę nie rozumiem, dlaczego w galerii robi się coś takiego (Gosia).

Po bardzo krytyczne:

(...) mnie to nie interesuje. Ja przychodzę zrobić zakupy, jak najszybciej i jakoś nie przepadam za chodzeniem tutaj godzinami (...) (Ola).

Ocena uzależniona jest od tematyki:

Nie no, zależy od tematyki, rzeczywiście: taniec czy - był kiedyś - pokaz mody wszyscy oglądali. Takie rzeczy ludzi interesują bardziej niż rowery, ich naprawa... roboty... chociaż nie. Przy robotach nie by to aż tak mało ludzi (Gosia).

(...) jak sa ciekawe wystawy, to zaglądam. (...) jak się pojawi coś ciekawego, to się o tym dowiem (Piotr).

Osoby aktywnie uczestniczące w eventach świadomie wybierają taki sposób spędzenia czasu. Zaglądają do galerii przy okazji zakupów bądź wracając z pracy:

Albo po drodze, wracajac z pracy gdzieś tam zajrze (...) (Piotr).

Wracajac z pracy, wbiegłam do galerii handlowej, żeby zobaczyć, co się dzieje ciekawego (Ewa).

Eventy propagujące pożądane społecznie postawy, zachowania, czy wartości są oceniane dużo wyżej, niż te kwalifikowane jako „rozrywkowe”.

M. (...) "Magnolia"65 (...) promuje akcję: oddaj krew. Co o czymś takim myślisz?

To jest akurat fajna sprawa... To ma jakieś tam znaczenie dla społeczeństwa. To nie (...) tylko reklama.(...) Pochwalam. Takie rzeczy warto promować w takich miejscach jak galeria, gdzie jest tylu ludzi, którzy robia zakupy (Gosia).

Dla niektórych uczestnictwo w eventach jest sposobem spędzania czasu wolnego:

Bo nie mam co robić w niedziele, bo, mówiąc szczerze, mam dzień wolny, i jak jest wnuczek w domu, to zabieram go i idziemy (Bogusia).

${ }^{65}$ Magnolia Park - galeria handlowa we Wrocławiu, jedna z największych w Polsce. 
Mam teraz wolne zajęcia i postanowityśmy się przejść (...) (Jagoda).

(...) jak sa ciekawe wystawy, to zaglądam. (...) jak się pojawi coś ciekawego, to się o tym dowiem, to będzie jakośs średnio raz w miesiącu. Tak średnio przyjmijmy (Piotr).

Osoby nastawione sceptycznie do eventów nawet nie wyobrażają sobie, że ktokolwiek może zainteresować się tym, co dzieje się na scenie. Należy przypuszczać, że ich kontestacja wynika z niezgody na galerię handlową jako zjawisko kulturowe.

\section{Wnioski}

Badaczka zdaje sobie sprawę, że społeczeństwo konsumpcyjne poddane jest szerokiej krytyce filozoficznej i ma negatywny wpływ na jednostki. Wie, że powstawanie galerii i rozwój handlu wpływa na organizację eventów $\mathrm{w}$ miejscach sprzedaży, co z kolei uczy przebywania na terenie centrum handlowego i spędzania tam wolnego czasu. Jednakże, świadomość negatywnej oceny zjawisk nie wyeliminuje ich z kultury, dlatego warto spojrzeć na zjawisko to od strony możliwości i szans, które otwiera. Zbyszko Melosik mówi, że teoria edukacyjna powinna zaangażować się $\mathrm{w}$ to, co popularne, by stanowiło ono zawsze ważne źródło "spotkania pedagogicznego". Chodzi o konstruktywne wykorzystanie go jako istotnego punktu wyjścia działań pedagogicznych ${ }^{66}$.

W eventach odnaleźć można wszystkie trzy wymiary uczenia się opisane przez Illerisa. Zachodzi ono w sytuacji społecznej - w instytucji społeczeństwa konsumpcyjnego. Wywołuje rozmaite emocje, są to głównie uczucia pozytywne, ale także odczucia związane z samoaktualizacją czy sprawdzaniem własnych możliwości na różnych polach aktywności. Przygotowane w sposób estetyczny i z dbałością o szczegóły (techniczne, historyczne), z wykorzystaniem najnowszych technik przekazywania wiedzy, przykuwa uwage uczestników. Pozwala na zdobycie wiedzy teoretycznej i praktycznej.

Wiedza ta zwykle nie buduje całkowicie nowych struktur poznawczych, raczej uzupełnia tę już posiadaną. Jest to więc uczenie akomodacyjne, które polega na tym, że ustanowione struktury poznawcze zmieniane są przez dysocjację i rekonstrukcję tak, że zdobyte wcześniej elementy uwalniają się od pierwotnego kontekstu i formują nowe struktury. „Procesy akomodacyjne są punktem wyjścia do wytworzenia postawy otwartości, wrażliwości, kreatywności, elastyczności" ${ }^{67}$. Dostarczają jednostce sposobności do działania, do zastosowania swej wiedzy $\mathrm{w}$ różnorodnych sytuacjach, niezależnie od

\footnotetext{
${ }^{66}$ Z. Melosik, Postmodernistyczne kontrowersje, s. 239.

${ }^{67}$ M. Bjerg, [cyt. za:] K. Illeris, Trzy wymiary uczenia się, s. 42.
} 
kontekstu $^{68}$. Żeby zaszło akomodacyjne uczenie się, konieczne są trzy czynniki: istniejące struktury, które mogą być rekonstruowane (np. nawyki żywieniowe), po drugie: jednostka potrzebuje lub pragnie zmobilizować energie do rekonstrukcji (wiedza o tym, jak zdrowo żyć oraz zagrożenie załamaniem zdrowia) i po trzecie: odczuwanie dużego przyzwolenia lub bezpieczeństwa, aby odważyć się wyjść poza posiadaną już wiedzę (informacja od lekarza i z poradnika o tym, jak zmienić nawyki i że to jest możliwe $)^{69}$.

Nie wszystkie tematy podejmowane przez wydarzenia kulturalne $w$ galeriach zgłębia się po zakończeniu pokazów. Częstokroć wiedza dana jest "tu i teraz" ze względu na zakres, wysoki stopień specjalizacji niedostępny dla zwykłego człowieka. Są też takie dane, których aktualizacja (bez szczegółowych studiów) podnosi jakość życia - może tak dziać się w odniesieniu do wiedzy z zakresu techniki. To ważne współcześnie, szczególnie dla mężczyzn (tezę tę opieram na obserwacji, że to oni stanowili większą część uczestników zarówno wystawy o robotach, jak i podczas „Święta Rowerów” w Galerii). Możliwość obcowania z przedmiotami współczesności pozwala na dokonanie kolejnej konstatacji: owe artefakty stają się pewnego rodzaju zabawkami, rekwizytami wprowadzającymi i nauczającymi konkretnej kultury ${ }^{70}$ - kultury współczesnej.

Zabawka zawiera w sobie treści kulturowe właściwej dla niej epoki lub epok minionych z zakresu kultury materialnej, duchowej lub społecznej i przekazuje je w sposób budzący określone postawy ludyczne ${ }^{71}$.

Jednocześnie, eventy mogą pomóc w oswajaniu z ogromem zachodzących zmian, zarówno przez podejmowaną tematykę, jak też przez sposób prezentacji tematów. Zabawa, która jest ważnym elementem wydarzeń, budzi emocje - często pozytywne - a to świadczy o wartości nadawanej działaniu.

Afektywny wymiar życia jest adaptacją, implikuje to także ciągłą asymilację sytuacji bieżących względem tych, które już miały miejsce - asymilacji, dzięki której powstają schematy afektywne lub względnie stabilne sposoby odczuwania czy reagowania ${ }^{72}$.

Wymiaru edukacyjnego eventów nie należy poszukiwać na poziomie wiedzy encyklopedycznej, a na poziomie tego, czego w codziennym życiu doświadczyć nie można z różnych względów - przykładem może być szansa jazdy na bicyklu (już nie ma ich w użyciu). Wydarzenia kulturalne pozwala-

\footnotetext{
68 Tamże.

${ }^{69}$ K. Illeris, Trzy wymiary uczenia się, s. 43.

${ }^{70}$ R. Kantor, Poważnie i na niby. Szkice o zabawach i zabawkach, Kielce 2003, s. 43.

${ }^{71}$ J. Bujak, Zabawka w Europie. Zarys dziejów, rozwój zainteresowań, Kraków 1988, s. 24.

72 J. Piaget, [cyt. za:] K. Illeris, Trzy wymiary uczenia się, s. 77.
} 
ją zaspokoić ciekawość i doświadczyć czegoś nowego. Warto na to zwrócić uwagę, bo to możliwość znalezienia odpowiedzi na pytanie: "Jak to jest?" w postmodernizmie jest szczególnie ważna: obecnie nie definiujemy siebie przez pryzmat urodzenia, mówiąc "Jestem synem mojego ojca”, jak działo się to w przeszłości, a właśnie przez doświadczenie, które decyduje o tożsamości. Mówimy więc "Jestem sobą, sam o sobie świadczę tym co robię i co wybieram". Doświadczenie stanowi źródło samowiedzy i układ odniesienia wobec innych ludzi ${ }^{73}$.

Choć wiedza przekazywana przez eventy nie daje pełnego obrazu rzeczywistości, dla wielu osób stanowi jedno z niewielu źródeł wiedzy, dla innych to także jedyna możliwość uczestnictwa w życiu publicznym, czego przykładem są osoby nieaktywne zawodowo i jednocześnie wykluczone cyfrowo. Eventy to propozycje bezpłatne, pod dachem, który zapewnia ciepło i bezpieczeństwo. To także odpowiedź na typowo ludzką potrzebę przynależności. Związek emocjonalny klientów z galeriami pobrzmiewa w słowach respondentów - wielokrotnie podkreśla się, że osoby przyszły „do swojej” galerii specjalnie po to, by „,coś zobaczyć” (Ewa), ,jakoś spędzić czas” (Bogusia).

We wnioskach należy podkreślić, że, choć jak powiedziano, potencjał edukacyjny eventów jest duży, poszukiwanie wiedzy stanowi zadanie uczącego się dorosłego. Nie każdy doświadczy emancypacji dzięki takim wydarzeniom. Niektórzy - jak badane studentki Małgorzata i Aleksandra - zjawisko potratują krytycznie i odrzucą ich potencjalną edukacyjność, inni - jak Ewa czy Piotr - świadomie będą zdobywać tam wiedzę.

W literaturze o galerii handlowej mówi się jako o instytucji społeczeństwa konsumpcyjnego. Stanowi ośrodek kultury konsumpcyjnej, podobnie jak muzeum - ośrodek kultury wysokiej ${ }^{74}$. W obliczu rosnącego znaczenia społecznego staje się ona instytucją społeczności uczącej się, dokąd zainteresowani zdobyciem wiedzy mogą wejść zaspokoić potrzeby wypływające z norm społeczeństwa wiedzy (ciągłe uczenie się). Istotna jest dostępność: może do nich zajrzeć każdy, przez cały tydzień, niemal przez całą dobę (centra czynne są zazwyczaj od 10.00 do 22.00), a eventy organizowane są często (w Pasażu Grunwaldzkim imprezy odbywają się minimum raz na dwa tygodnie, podobnie w Galerii Dominikańskiej). Dostępność wiedzy ważna jest szczególnie dla ludzi dorosłych. Wielu z nich z reguły - poza organizacją, w której pracują - rzadko ma kontakt z innymi instytucjami edukacyjnymi. Event jest łatwo dostępny, a jego potencjał edukacyjny - dzięki szerokiemu wachlarzowi sposobów przekazywania treści, odwoływaniu się do emocji, podejmowaniu tematów ciekawych ważnych społecznie - duży.

${ }^{73}$ W. Jakubowski, Wstęp [w:] Kultura i edukacja, s. 8-9.

${ }^{74}$ K. Illeris, Trzy wymiary uczenia się, s. 113. 
Kultura jest kluczem do własnej egzystencji ${ }^{75}$. Galeria handlowa (zarówno pod względem architektonicznym, jak i społecznym, ze wszystkimi podejmowanymi przez nią działaniami) stanowi element współczesnej kultury miejskiej. Event pokazuje wybrane obszary rzeczywistości. Nawet zjawisko tak pozornie nieedukacyjne daje więc szansę uczestnikom na większe rozumienie siebie w kontekście otaczającego świata. Potwierdza się to, co zostało powiedziane o edukacji nieformalnej - jest niezauważana. W przypadku eventów nikt nie myśli o niej - jest wręcz efektem ubocznym działań promocyjnych.

\section{BIBLIOGRAFIA}

Bujak J., Zabawka w Europie. Zarys dziejów, rozwój zainteresowań, WUJ, Kraków 1988.

Chwałek J., Nowoczesny sklep, WSiP, Warszawa 1993.

Encyklopedia historii gospodarczej Polski do 1945 roku, t. 1 A - N, red. A. Mączaka, WP, Warszawa 1981.

Galbraith J.K., Społeczeństwo dobrobytu, państwo przemystowe, przekł. J. Prokopiuk, Z. Zinserling, PIW, Warszawa 1973.

Goldman D., Olfaktoria. Blog; http:/ / www.olfaktoria.pl/2014/09/jak-pachna-polskie-sklepy, [data dostępu: 1.05.2017].

Gujska-Szczepańska T.,Wszystko o galeriach handlowych i supermarketach. Wywiad z Krystyna Stowik, http:// bibulamilanowska.eu/index.php/ludzie/749-wszystko-o-galeriachhandlowych-i-supermarketach-wywiad-z-krystyna-slowik, [data dostępu: 29.04.2017].

Historia kultury materialnej Polski w zarysie, tom VI, Od 1870 do 1918, red. B. Baranowski, J. Bartyś, T. Sobczak, Ossolineum, Wrocław 1979.

Illeris K., Trzy wymiary uczenia się. Poznawcze, emocjonalne i społeczne ramy wspótczesnej teorii uczenia się, przekł. A. Jurgiel, red. M. Malewski, Wydawnictwo Naukowe DSWE TWP, Wrocław 2006.

Jakubowski W., Edukacja w świecie kultury popularnej, Oficyna Wydawnicza Impuls, Kraków 2006.

Kultura i edukacja (konteksty i kontrowersje), red. W. Jakubowski, Oficyna Wydawnicza Impuls, Kraków 2008.

Kultura jako przestrzeń edukacyjna - współczesne obszary uczenia się osób dorostych, red. W. Jakubowski, Oficyna Wydawnicza Impuls, Kraków 2012.

Kantor R., Poważnie i na niby. Szkice o zabawach i zabawkach, MAC Edukacja, Kielce 2003.

Kargul J., Obszary pozaformalnej i nieformalnej edukacji dorostych. Przestanki do budowy teorii edukacji całożyciowej, Wydawnictwo Naukowe DSWE TWP, Wrocław 2005.

Kłoskowska A., Kultura masowa: krytyka i obrona, Wydawnictwo Naukowe PWN, Warszawa 2005.

Konarzewski K., Jak uprawiać badania oświatowe. Metodologia praktyczna, WSiP, Warszawa 2000.

Leksykon marketingu, red. J. Alktorn, T. Kramer, PWE, Warszawa 1998.

Makowski G., Światynie konsumpcji. Geneza i społeczne znaczenie centrum handlowego, Wydawnictwo TRIO, Warszawa 2003.

Malewski M., Modele pracy edukacyjnej z ludźmi dorostymi, Teraźniejszość - Człowiek - Edukacja, 2000, 1.

${ }^{75}$ W. Jakubowski, Edukacja w świecie kultury popularnej, Kraków 2006, s. 8. 
Malewski M., W poszukiwaniu teorii uczenia się ludzi dorosłych, Teraźniejszość - Człowiek Edukacja, 2006, 2.

Mead M., Kultura i tożsamość. Studium dystansu międzypokoleniowego, PWN, Warszawa 1978. Melosik Z., Postmodernistyczne kontrowersje wokót edukacji, Wydawnictwo Edytor, Torun Poznań 1995.

Pietrasiński Z., Sztuka uczenia sie, WP, Warszawa 1964.

Pilch T., Bauman T., Zasady badań pedagogicznych. Strategie ilościowe i jakościowe, Wydawnictwo Akademickie Żak, Warszawa 2001.

Ritzer G., Magiczny świat konsumpcji, przekł. L. Stawowy, Muza, Warszawa 2001.

Romanowska K., Więcka A., Potknięci przez mall, „Newsweek”, nr 7, 21.10.2001.

Rudnicka K., Edukacja mimowolna. W poszukiwaniu nowych przestrzeni edukacyjnych w społeczeństwie konsumpcyjnym, [w:] Kultura i edukacja (konteksty i kontrowersje), red. W. Jakubowski, Oficyna Wydawnicza Impuls, Kraków 2008.

Siemak-Tylikowska A., Uczymy się społeczeństwa przez uśmiech, Kwartalnik Pedagogiczny, 2005, 3(197).

Stownik marketingu, red. J. Słupski, Seria: Biblioteka Profesjonalisty, Peter Collin Publishing, Wydawnictwo Wilga, Warszawa 2000.

Sulima R., Antropologia codzienności, WUJ, Kraków 2000.

Toffler A., Trzecia fala, przekł. E. Woydyłło, PIW, Warszawa 1997.

Wikipedia. Wolna encyklopedia, https://pl.wikipedia.org/wiki/Convenience_store [data dostępu: 13.05.2017]. 